Watershed Days on the Treaty Line, 1836-1839

One of the misconceptions about Iowa's founding is that white settlement was, above all, an agricultural process. While sod-busting was important, Yankee enterprise was equally an affair of commercial development on the creeks and rivers. From the surveying of the first towns after Black Hawk's War, Iowa's economic development was an urban commercial enterprise centered on waterways as well as prairies. Nothing better illustrates the centrality of urban investment and river commerce to the making of Iowa than the American Fur Company traders who brought consumer capitalism to Johnson County in the years immediately preceding Iowa's organization as a U.S. territory, with Iowa City as its capital. Local historians list three traders in the county during the late 1830s: John Gilbert and Wheaton Chase on the Iowa River, and Alexander Ross along the Cedar. While Chase did not appear until 1837, and Ross fled the area in 1838 , all three men arrived to trade with the Meskwaki (whites called them "Fox"), who had migrated to the Iowa River, where it crossed the northern boundary of Keokuk's Reserve.

Between Black Hawk's War of 1832 and the creation of Iowa Territory in 1839, the loosely allied Sauk and Meskwaki were compelled to make three major land cessions: the First Black Hawk Purchase of 1832, the cession of Keokuk's Reserve in 1836, and the Second Black Hawk Purchase of 1837 (fig. 1). After the first of these treaties, the Sauk and Meskwaki began to withdraw and establish new villages along the rivers of the interior. As they retreated, the fur traders followed. When John Gilbert arrived in Johnson County, there were roughly 1,500 Meskwaki living on the Iowa River, by far the largest population of Meskwaki anywhere at the time. By contrast, the Sauk migrated further west, to the Des Moines River, along with at least one Meskwaki village (Wapello's). By 1834 the majority of Meskwaki, led by Poweshiek and Wapashashiek, lived along the northern boundary of Keokuk's Reserve in Johnson County, where the boundary line crossed the Iowa River.

Keokuk's Reserve had been carved from the First Black Hawk Purchase as a reward to Keokuk, the Sauk leader who refused to 


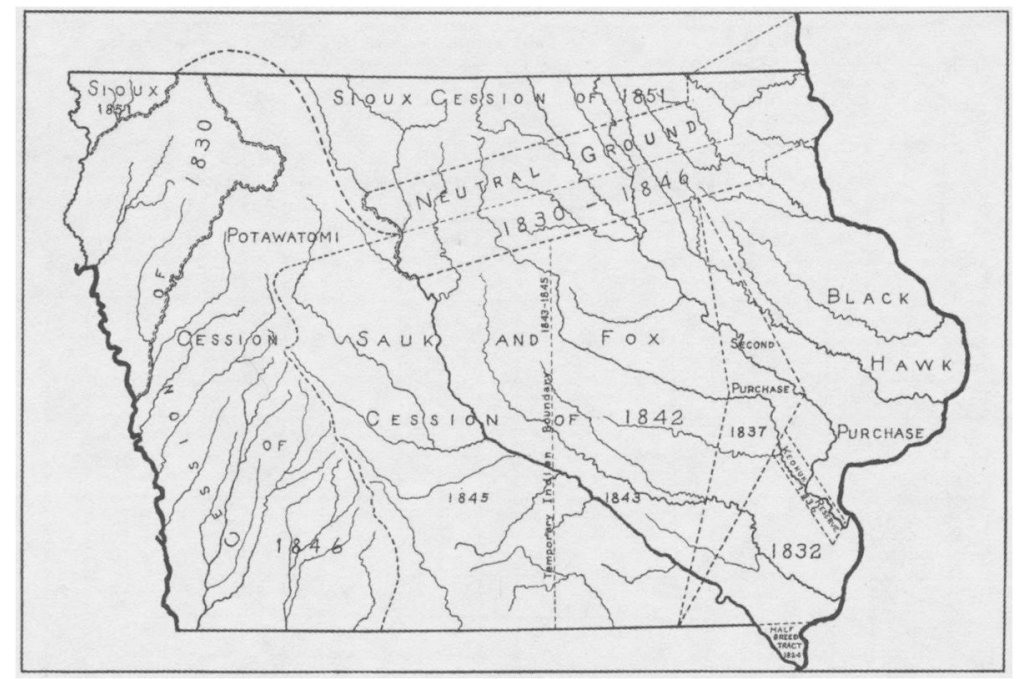

Fig. 1. Indian Land Cessions, 1832-1860. (The State Historical Society of Iowa)

Fig. 2. Enlargement: the Iowa River with Keokuk's Reserve. (The State Historical Society of Iowa)

join Black Hawk's War. The Reserve

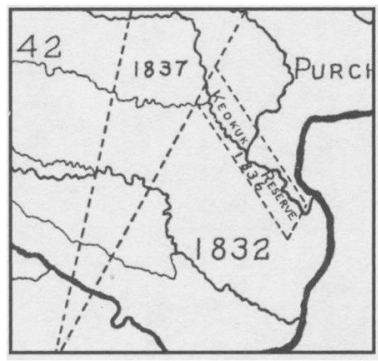
stretched along both sides of the Iowa River, encompassing some 400 square miles (fig. 2). Preferring negotiation to open resistance, Keokuk and his followers had avoided the war's catastrophic conclusion. In August 1832, the U.S. Army, assisted by the steamboat Warrior, massacred some 500 Sauk and Meskwaki men, women, and children on the east bank of the Mississippi at the mouth of the Bad Ax River. The Battle of Bad Ax, as it came to be known, marked the end of the Sauk and Meskwaki struggle to maintain control of Saukenuk, the Sauk's primary village on the lower Rock River (present-day Rock Island). In the treaty negotiations that followed the Battle of Bad Ax, the United States was able to appropriate millions of acres of land on the west side of the Mississippi through the First and Second Black Hawk Purchases and the cession of Keokuk's Reserve. Johnson County was at the geopolitical center of these land transfers. One or more borders of each of the three treaty cessions lay 


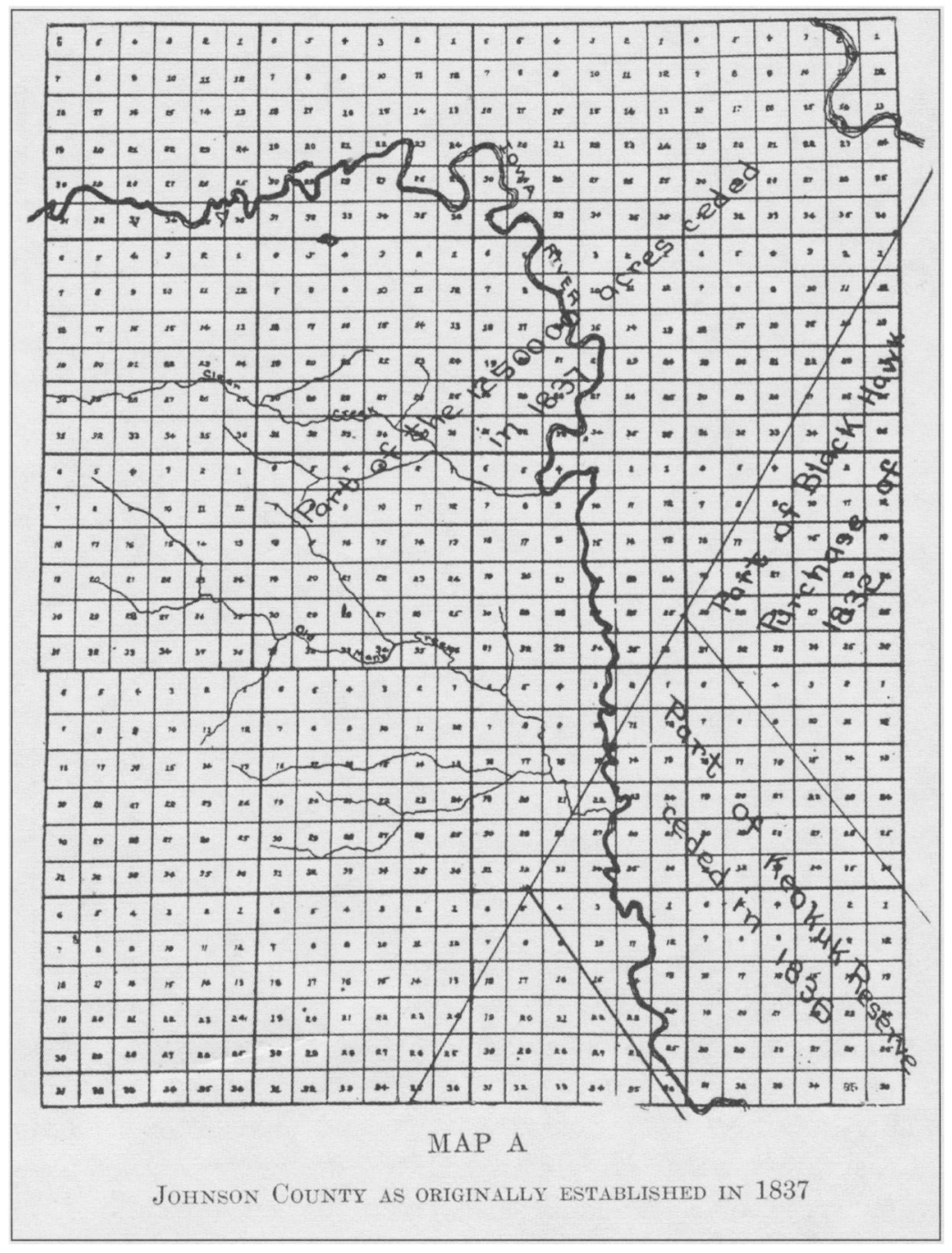

Fig 3. Johnson County in 1837: Treaty Lines. (Charles Ray Aurner, Leading Events in Johnson County History [1912]. The State Historical Society of Iowa)

within the county, putting it at the heart of changes that made the 1830 s so momentous in the making of Iowa (fig. 3).

With Black Hawk's defeat, Yankee settlers began streaming over the Mississippi. Crossing on keelboats, flatboats, steamboats, and dugout canoes, they used a network of creeks, rivers, and Indian 
trails to navigate the interior. When they arrived at settlement sites along the rivers and creeks of Johnson County, they would find the land already peopled with Native American villages and U.S. fur traders: the Meskwaki, led by Poweshiek and Wapashashiek, and the clerks and workers of Gilbert's trading post, who had followed them there. Gilbert's Meskwaki business was the catalyst for lightning-fast economic, ecological, and cultural changes that would reshape the land and lead to the founding of Iowa City. Both Gilbert and his competitor Wheaton Chase worked for John Jacob Astor's and Ramsay Crooke's American Fur Company (AFC), managed by Pierre Chouteau out of St. Louis, and run locally by William Phelps of the Sac and Fox Outfit. Phelps and his wife Caroline ran their own trading post among the Sauk on the Des Moines River while managing the conglomerate of AFC posts (the Sac and Fox Outfit) that included Gilbert's.

With a near monopoly of the Indian trade in the Upper Mississippi River Valley, the American Fur Company epitomized the urban and industrial character of the changes that came to the Iowa River after Black Hawk's War. Shipping trade goods (cloth, blankets, hardware) from their New York warehouses east on the Erie Canal, or by sailing ship to New Orleans, the AFC supplied traders up and down the Mississippi, using St. Louis as a central distribution center, at the juncture of the Missouri, Illinois, and Mississippi Rivers. From St. Louis, Prairie du Chien, and Mackinac Island, furs and skins harvested by Native American hunter-trappers throughout the upper Midwest were assembled and transported by keelboat, steamboat, and sailing ship to processors and consumers along the East Coast and in western Europe. With its network of far-flung consumers and investors in New York, New Orleans, and St. Louis, the AFC was at the center of a cosmopolitan enterprise that, in the 1830s, connected the Iowa River to the Atlantic world. As a modern industry, the fur trade relied at every point on Native American labor. Its competitive structure encouraged over-hunting, rapidly stripping the upper Midwest of otter, beaver, muskrat, and deer: typical shipments of Sauk and Meskwaki products to St. Louis, for example, consisted in April 1833 of 65 dressed skins, 39 pairs of moccasins, and 211 bags of feathers; in November 1833 of 28 bundles of tobacco, 296 of beeswax, 22 of maple sugar, 274 muskrats, 48 raccoons, 68 shaved deer skins, and 84 pounds of beeswax; and, in 1836, of 25 
bear hides, 1 barrel and 1 sack of beeswax, 540 pounds of deer skins, and 4 beavers (Peterson 66).

By the time the Sauk and Meskwaki had been forced onto Keokuk's Reserve in 1833, the land along the Iowa River was already depleted of animal resources. Both groups were under tremendous economic and ecological pressure. Between 1833 and 1845, the combined population of Sauk and Meskwaki decreased by more than fifty percent, from roughly 6,000 . Scarce resources and crowded hunting grounds, poverty, and malnutrition were aggravated by chronic warfare, epidemic illness, and alcoholism-which increasingly took hold in the 1830s. As conditions worsened, the Sauk and Meskwaki went deeply into debt to the fur traders who supplied them with goods on credit, such as gunpowder, shot, salt, and fabrics, all of which had become necessities for hunting and village life. Tribal poverty and indebtedness were then skillfully exploited at the treaty table by U.S. negotiators who extracted enormous land cessions in return for regular cash payments ("annuities") to be sent to tribal leaders by the federal government. These annuities were pocketed, in turn, by fur company investors and traders who had extended goods and services to Native hunters on credit.

In Johnson County, Gilbert was ideally situated to exploit the three treaty cessions that, between 1832 and 1837, forced the Sauk and Meskwaki to relocate every few years. Living within, or at the edge of, not-yet-ceded Indian land, Gilbert profited from trade with Native hunters and harvesters, while anticipating their imminent removal. It should come as no surprise, then, that in addition to exchanging AFC trade goods for furs, skins, deer tallow, and beeswax, Gilbert was also a small-time land speculator, surveying future towns, locating mill sites, and buying interests in the land around his post. In 1838, for instance, Gilbert hired surveyors to lay out two "paper towns" on the Iowa River: Se-pa-na-mo, or Stump Town, at the juncture of the Iowa and English Rivers, and Napoleon (at present-day Napoleon Park in south Iowa City). He also participated indirectly in the construction of two sawmills, one at Old Man's Creek, and the other on the Dubuque Road at Rapid Creek, and made at least one trip to Lafayette County, Indiana to sell land he had purchased downriver near Wapello.

There were traders like Gilbert on virtually every major river in southeast Iowa. Some ran small posts called "whiskey stores" or 
groceries. Other, larger posts were located at or near present-day Burlington, Muscatine, Clinton, Rochester, Eddyville, Moscow, Iowa City, Iowaville, Keokuk, and Ottumwa. The stores consisted of one or more log cabins (with puncheon floors, and few if any windows) surrounded by fencing, storage sheds, and outbuildings. These were inevitably built on river landings where trade goods (nails, whiskey, bacon, salt, sugar, tea, calico, blankets, thimbles, beads, and "Bateman's [opium] Drops") were unloaded from keelboats or canoes, and where furs or skins were packed.

Little is known about Gilbert's life before he appeared at the mouth of Snyder Creek in Johnson County. Sometime in 1835, he visited Poweshiek's village a mile north on the Iowa River and received permission to live on Meskwaki land in exchange for two barrels of whiskey. Poweshiek reportedly sealed the deal by liberally sampling Gilbert's wares (Peterson 72). Gilbert traded at Snyder Creek until 1837, when he built a second, larger post at Napoleon, less than a quarter mile from Poweshiek's village, and struck out on his own as an independent trader. Settlers testify that Gilbert spoke Meskwaki "with some French thrown in," and he may have learned the trading business at Green Bay in then Michigan Territory. He seems to have changed his last name from "Prentice" to "Gilbert" sometime before arriving in Johnson County, in order to escape bad investments in the Ohio canal business. In March of 1839, he died of complications from gonorrhea, leaving no heirs or kin. At his death Gilbert was moderately wealthy in land, but rather deeply in debt to his urban trading suppliers: his land holdings along the Iowa and Cedar Rivers were sold to pay his creditors, including the Muscatine firm of Davis and Moon (Peterson 68-9).

While Gilbert depended upon trade goods shipped from Muscatine or St. Louis, he relied equally upon the seasonal hunting patterns of his Meskwaki trading partners, who depended in turn upon the wooded creeks and bottomland of the Iowa River for plant and animal resources. To a remarkable degree, given the illness, treaty cessions, war, and poverty of the 1830s, the Meskwaki of Poweshiek's and Wapashashiek's villages continued to follow seasonal cycles of hunting and harvesting that were deeply rooted in their history and environment. During the summer, they lived in multi-family lodges, in large, relatively permanent summer villages situated on river terraces or flood plains along the river. There they harvested corn, 
squash, and other crops planted in the rich soil of bottomlands replenished by frequent floods. In those days, the Iowa River was lined with marshy sloughs that filled with water whenever the river rose. As a result, the river valleys (unlike the open prairie) gave rise to an abundance of trees and plant cover that could shelter and support large animal populations throughout the year. Every fall, as cold weather approached, Poweshiek's and Wapashashiek's villages broke up into smaller family units who dispersed to winter hunting camps, usually in sheltered creek valleys. There they harvested muskrat, raccoon, otter, deer, and occasionally beaver. In the early spring, these hunting groups reunited, first to make maple sugar in the stands of maple trees that flourished throughout the watershed and then to reconstitute their summer villages along the Iowa River, plant their crops, and begin the cycle anew.

Similar seasonal cycles had been followed by Native peoples in the western Great Lakes and Upper Mississippi River Valley for at least two thousand years. The French fur trade had first infiltrated this seasonal round in the mid-seventeenth century, but without changing its basic outline. The Sauk and Meskwaki were thoroughly acquainted with the French and British trade goods that had circulated through the Great Lakes and Upper Mississippi Valley for more than two hundred years. By the 1820s, however, the British and French traders had withdrawn, and the American Fur Company dominated the seasonal Indian trade. Like the French and British before them, American fur traders insinuated themselves into Sauk and Meskwaki hunting patterns by supplying winter hunting camps with vital supplies on credit, to be repaid in the spring with skins, furs, and other forest products. In fact most traders, including Gilbert, did not wait for Indian hunters to return in the spring, but visited them in their winter camps to claim their skins and pelts, or trade for more.

By the early 1830s, the American Fur Company was expanding across the Great Plains and Rocky Mountains in search of beaver and buffalo. Fur-bearing animals along the Upper Mississippi had become depleted, and the trading cycle that had once tenuously supported Sauk and Meskwaki villages now severely impoverished them. Debt and crowded hunting grounds increasingly pitted the Siouan-speaking Ioway, Ho-Chunk/Winnebago, and southern Sioux against the Algonquian-speaking Sauk and Meskwaki. In the 
process, U.S. treaty negotiators found themselves well positioned to demand land cessions in return for regular annuity payments that could be used to rectify debt to American fur traders (i.e., the Indians' "just creditors").

Gilbert was well-versed in the logic of treaty annuities and land cessions. In September 1836 he had attended the treaty council at Davenport/Rock Island at which the Meskwaki and Sauk relinquished Keokuk's Reserve. The council was also attended by Territorial Governor Henry Dodge and a thousand Ho-Chunk, Sioux, Ioway, Meskwaki, and Sauk-including the aged Black Hawk. At some point during the meetings, Gilbert met two travelers named Philip Clarke and Eli Myers from Elkhart County, Indiana. They were seeking land, and Gilbert invited them to visit his trading post on the northern border of Keokuk's Reserve. He reminded them that under the terms of the new treaty the Meskwaki would be required to leave the area in less than a year. In fact, Poweshiek's and Wapashashiek's villages would remain in Johnson County for more than three years. And the Meskwaki never left the Iowa River watershed altogether-where they live today-despite aggressive efforts to force them over the Missouri into Kansas.

Upon meeting Gilbert, Myers and Clarke followed him to Johnson County, where they accepted his hospitality long enough to stake two claims, making them the first Yankee settlers in Johnson County. But first, Myers and Clarke had to meet the Meskwaki, who also controlled the land. Gilbert took them to meet Poweshiek at the Meskwaki village, where they reportedly ate a feast together in a wickiup. As Myers and Clarke left for Indiana, Gilbert promised to "protect" their claims over the winter until they returned. The following May the men reappeared, this time with their families and four other single men. More emigrants followed. John Cain, William Sturgis, S.B. Mullholland, and the Earhart brothers all roomed at Gilbert's post that summer until their claims could be staked and shelters raised. By the end of 1837 , thirteen more white families had settled in the vicinity of Gilbert's trading post, which served as a combined inn, tavern, grocery store, and city hall, as jumping-off place and catalyst to settlement (Peterson 71). 
SHE-MO-KO

Gilbert's gamble on the land along the Iowa River was paying off. Now his post was servicing new settlers as well as supporting trade with the Meskwaki. With the help of local men in need of work, he built his second, larger trading post closer to Poweshiek's village and broke off his association with the American Fur

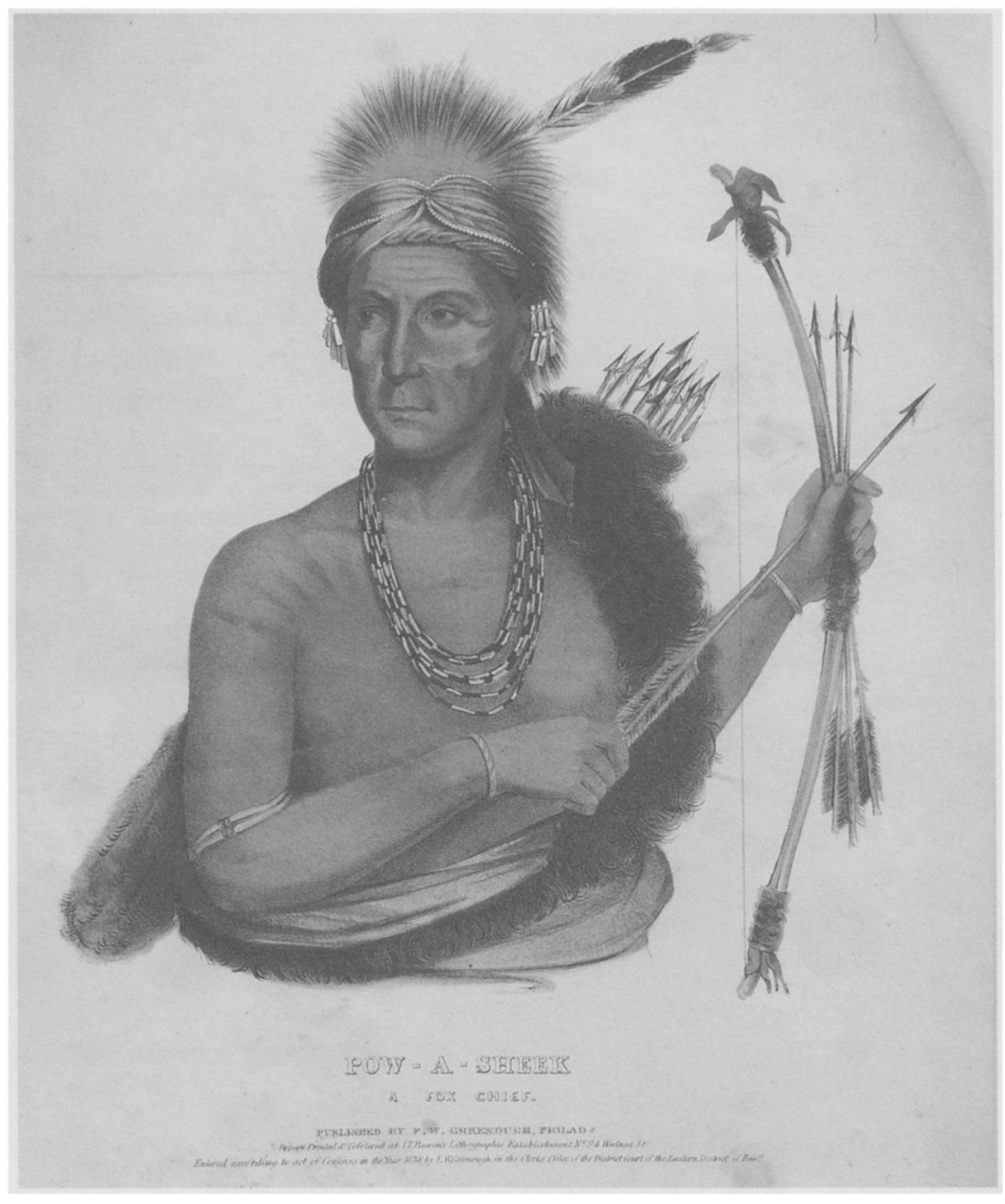

Fig. 4. George Cook painted this portrait in 1837 during Poweshiek's visit to Washington, D.C. with the large Sauk and Meskwaki delegation. (McKenney $\&$ Hall's History of the Indian Tribes of North America, hand-colored lithographs, printed 1837-1843. The State Historical Society of Iowa.) 
Company. Instead of shipments from Pierre Chouteau in St. Louis, Gilbert ordered his nails, whiskey, and opium drops from Davis and Moon of Muscatine. He was so confident of his move that, on the Fourth of July, 1837, he held a grand opening for the new post with a whiskey celebration for both the neighboring Meskwaki and the new male settlers. Henry Felkner rode to Muscatine for whiskey, while the other Yankees made a U.S. flag on which they attempted to sew an eagle, but instead made a goose, surrounded by scraps of red, white, and blue. The participating Meskwaki responded to the festivities with "She-mo-ko," an expression that is hard to translate except, perhaps, by rolling your eyes to indicate that something is "too much," or "over the top" (Bennett, personal communication).

By summer's end, Gilbert had begun to dream of founding the future seat of Johnson County on the land around his post. He would name it Napoleon, after the French emperor who sold the Iowa River to the United States in 1803 as part of the Louisiana Purchase. But Gilbert had a new problem. The American Fur Company had sent Wheaton Chase to compete with Gilbert for the Meskwaki trade, and Chase was constructing his trading post directly across the creek from Gilbert's new establishment. As winter fell, there were two white traders on the Iowa River at "Napoleon," both competing for the "rats" and coons, beaver, deerskin, and deer tallow harvested by the Meskwaki.

One local historian detailed the hunting practices used by the Meskwaki in Johnson County during that winter of $1837-8$ :

[L]ate in the fall...the Indians nearly all left for the winter hunt. They went up the different water courses, the Iowa and English rivers, Old Man's creek, \&c. Their practice was to go at once as far as they intended and then hunt the ground towards home. They spent the fore part of the winter far up the streams and then hunted back by slow stages, traveling a day, going in to camp, hunting and trapping as long as game was plenty, then moving on. (Anonymous 583)

While the Meskwaki were hunting their way down the rivers, however, Gilbert was growing anxious about his competitor Chase. When an Indian messenger arrived one day in February to report 
that the Meskwaki had arrived on Old Man's Creek, ${ }^{1}$ Gilbert was acutely concerned that Chase would beat him to the trade. So he devised a plan to reach the Meskwaki first. Calling on the aid of a settler named Hamilton, Gilbert prepared to pack in a hundred pounds of trade goods to the Meskwaki camp and meet the hunters ahead of Chase, to "take the cream of their trade" and "swap before he got in" (Anonymous 583). The winter was mild and the river was open, but there was no way to cross. Finding Chase's canoe on shore, Gilbert and Hamilton stole it and, crossing the river, beat Chase to the Meskwaki.

When Chase discovered that his canoe was missing, he concluded that Gilbert had stolen it and immediately built a raft of logs, taking some iron-socketed pushing poles from a keelboat tied up in a creek (Anonymous 585-6). Crossing over on his raft, together with a métis (Native American/Euro-American) interpreter named Joseph Coata, Chase started after Gilbert, whose tracks were visible in the snow. When he reached Gilbert and Hamilton, Chase found them in conversation with the Meskwaki; but they had not yet made the swap. Although Gilbert spoke Meskwaki, Chase had an advantage in Coata, the French métis interpreter, who forcefully informed the Meskwaki that Gilbert had stolen Chase's canoe, had neglected the old Indians left at home, and that his sympathies were with the whites. As a result, Coata and Chase got more than three-fourths of the furs, and Gilbert was beaten at his own game (Anonymous 585-6; Peterson 82).

While the Meskwaki were using the waterways for hunting and travel in the early spring of 1838, the river's hydraulic energy was about to be put to another purpose. As the Meskwaki returned to plant summer crops, Henry Felkner, Eli Myers, and Pleasant Harris began building a sawmill on Rapid Creek. Mill construction relied on nails, iron parts, and imported food supplies (bacon and corn) from St. Louis and Muscatine. Myers, Felkner, and Harris began raising the mill in March. The iron parts had been shipped from St. Louis to Chase's post by keelboat. But as the mill progressed, food ran low, so Felkner walked some eight miles to Gilbert's post, borrowed Gilbert's

1. The Meskwkaki name for the creek is Pa-Pa-To-See-Po, which settlers translated as Old Man's Creek, meaning that place where Meskwaki noncombatants-namely old men, women, and children-concealed themselves when their warriors had gone to war with the southern Sioux, or the Ho-Chunk (Winnebago). 
horse, and rode to Muscatine to buy a seventy-eight pound side of bacon. Carrying the bacon back in a coffee sack before him, Felkner returned only to find that Gilbert was furious because he had needed his horse in the interim. Felkner was too proud to ask Gilbert for the horse again: "[I]nstead of asking him for the use of his horse to take the bacon home, notwithstanding that the prairie was flooded with water, I threw the seventy-eight pounds of bacon on my back, and plunged through sloughs and ponds, and reached home, a distance of eight miles" (Anonymous 586-7; Peterson 83). Four years later, Felkner's, Myers's, and Harris's mill supplied the lumber that was used to construct the (old) Capitol building in Iowa City. Raised on a high bluff, the Capitol site was chosen for aesthetic reasons, but also because it was dry, elevated above the creeks and prairie sloughs, maple trees, muskrats, and river trade below.

\section{DREAM CITY}

Six white men lived with Gilbert at his Napoleon trading post, according to the census of 1838 . Early settlers also write that "a very tall black man" named Mogawk (about whom nothing else is recorded) also lived with Gilbert, along with "an old Indian woman" named Jennie who "spoke pretty good English" and cooked and cleaned for the post. Neither Jennie nor Mogawk were enumerated in the census because only whites were counted (Peterson 83-4). Throughout its history, the European fur trade depended on the labor of Native or métis women who had married into, or worked for, isolated trading establishments such as Gilbert's. The trade was also dependent upon African-American slave labor, although evidence of this is scarce for eastern Iowa. Slave labor could be easily hired or bought in St. Louis and south along the Mississippi. In the mid-183os, for example, William Phelps's wife Caroline hired several young black women to help care for her children at the Des Moines River trading post. According to Mrs. Phelps's diary, one of these women returned to Missouri to visit her husband; while the woman herself was perhaps not a slave, her husband was. ${ }^{2}$

Phelps's and Gilbert's living arrangements reveal that the creation of Iowa was never a question of whites only-any more than

2. When Mrs. Phelps wrote of hiring black women, she may mean she hired them from a white slave owner. (Peterson 64) 
it was a matter of farms and farmers only. The French and British fur traders had always depended upon a multi-ethnic work force, and John Gilbert was no different. Moreover, the Meskwaki and métis population of Johnson County outnumbered Euro-Americans by roughly one thousand to one. Both life and commerce depended upon the Meskwaki, as Gilbert well knew. In the winter of 1837, for instance, it was lonely along the Iowa River. Most of the Meskwaki were away at their hunting camps, and the young white men who helped build Gilbert's new post had migrated to Muscatine or New Boston (Illinois) to earn winter money by chopping wood for steamboats on the Mississippi. Isolated and bored, Gilbert and a restless Pleasant Harris decided to walk through the snow to Burlington to petition the territorial legislature for roads and a mail service. When they arrived to present their case, Governor Dodge asked Gilbert for the population of the settlement around the trading post, and Gilbert responded, "Fifteen hundred." The governor was surprised at the large number and, when Gilbert was asked "how he dared tell the governor such a lie," his response was, "he did not ask what color they were" (quoted in Peterson 80-81).

The joke, of course, is that Gilbert counted the Meskwaki villagers as legitimate residents despite their color. By playing upon the governor's ethnocentric, racist assumptions, he used the large Meskwaki population to obtain a post office for Johnson County. But Gilbert's response to Dodge also registers the degree to which the Meskwaki counted a great deal (albeit at great cost to themselves) in the economic and political founding of Johnson County. Poweshiek's and Wapashashiek's villages made up the single most substantial and significant population in Johnson County: without them, neither the fur trade nor the land business, nor the state capital would have emerged on the Iowa River when and where it did.

Gilbert made more than one trip to Burlington to call the Governor's attention to Johnson County. In the spring of 1838 he hired George Bumgardner of Muscatine County to survey his dream city, the Napoleon town site, for "half a bushel of corn, one deer skin, six yards of calico and a pair of shoes," and \$75.00 (never paid, Peterson 83). Napoleon was huge by territorial standards: two miles long and at least half a mile wide, with broad streets, parks, and boat landings. But it was a classic paper town that contained only two log structures: a claim cabin and a one-room courthouse. Napoleon's 
unreality is underlined by the fact that the Meskwaki were living within its borders, but were not represented in Bumgardner's plans (Peterson 83-4). Notwithstanding, Gilbert traveled to Burlington to argue that Napoleon be named the seat of Johnson County. His request was granted. Within a year, Territorial Governor Robert Lucas would visit Napoleon and, finding the landscape aesthetically pleasing, determine that a new state capital should be staked out nearby, on the bluffs above Felkner's mill. A new post office followed in 1839, with Gilbert-then on his deathbed-appointed the first postmaster.

To celebrate the creation of Napoleon, Gilbert decided to hold another Fourth of July celebration at the trading post. Jennie prepared the dinner, after which Gilbert went with a group of men to visit Poweshiek. An interpreter named Stephens reportedly explained the significance of the day to the Meskwaki, after which, according to a single document in the Iowa State Historical Society, Poweshiek made a brief speech, translated presumably by Stephens:

I want to live where men are free! Soon I will go to a new home. You will plant corn where my dead sleep, our town, the paths we have made, the flowers we have loved will soon be yours. I have moved many times, I have seen the white man put his foot in the track of the Indian and make the earth into fields and gardens. I know I must go far away and you will be so glad when I am gone. You will soon forget the lodge fires, and the meat of the Indian has ever been free to the stranger.... (Coxe n.d. Peterson 84-50)

While the origin of these words is undocumented in any other source, they refer accurately to Poweshiek's historical situation: "I have moved many times..."; "You will plant corn where my dead sleep... and make the earth into fields and gardens..."; and "You will soon forget the lodge fires, and the meat of the Indian [that] has ever been free to the stranger." The speech also forecasts that white settlement would obliterate the memory of everyday hospitality, mutuality, and intimacy among peoples who, in spite of economic inequities and social conflict, faced contingency and scarcity together. 
PATTERNS OF INTIMACY AND VIOLENCE

Cross-cultural contact between Euro-American and Meskwaki women was likewise mediated by plants and animals of the watershed. After Gilbert's Fourth of July celebration, for example, Poweshiek was visiting the Napoleon town site when he noticed the sad faces of the people. "Why so sorry?" he reportedly asked. The settlers told him that a woman who lived in the claim cabin, Mary Clark Smith, had gone into labor and that the birth was so difficult they feared that both the mother and baby would die. Poweshiek immediately sent for his own mother, Singing Bird, who, arriving with two other Meskwaki women, administered herbs or roots in a drink and successfully delivered Smith's baby (Coxe, 1912). The names of the plants used by the Meskwaki are not recorded but were possibly white baneberry or wild yam.

Less than a year later, on the Des Moines River, Caroline Phelps and the women of the trading post celebrated a Fourth of July of their own with the Sauk women and children of the neighboring village. Mrs. Phelps's diary explains that her husband and other men had gone to build a new trading post on land recently sold by the Indians, while the Sauk men had gone out "on a war path." When Independence Day dawned, Mrs. Phelps killed a cow, while several Meskwaki women came over the river to make the coffee, fry bread, and boil the beef. When the food was prepared, the boys at the trading post fired a cannon, and some 180 women and children crossed over for the feast. The event ended with a speech, presumably delivered by one of the women of the Sauk village; but Mrs. Phelps concludes by criticizing her guests: "And they sure enough eat," she observes, "for they finished the whole, every bit in just half an hour by the clock. They rubbed their greasy hands on their hands, shook me by the hand, made a speech and departed" (Phelps 233).

Mrs. Phelps's tone implies that while cross-cultural contact could be intimate and mutual, it was shaped by racial and class hierarchies. At Mrs. Phelps's Fourth of July picnic, the AFC trading post provided the cow-but the Sauk women did the labor of cooking. Race and class could be set aside by feasting and ritual, but not necessarily erased. Similarly, while hunger and medical emergencies were common on the trading frontier, they did not always result in social harmony or a cure. In 1839, members of Poweshiek's family were successfully treated for illness (possibly smallpox) by 
a local doctor, Henry Murray, upon whom, in gratitude, Poweshiek bestowed a ceremonial feather cape (Anderson 161-4). Five years earlier, however, before migrating to Johnson County, Poweshiek's village on the Cedar River had endured a disastrous smallpox epidemic. This epidemic was remembered for many years after by farmers and townspeople who claimed to find the skeletons of dead Meskwaki washing up along the banks of the Cedar, with bullet holes in their skulls. The settlers believed these were the remains of villagers who had been shot by the Meskwaki villagers as soon as they contracted smallpox, so that they would not infect others. But this explanation is almost certainly untrue. While the skeletons may have come from burial sites washed out by the river's changing course, the ones with bullet holes were more likely those of a Meskwaki tribal council massacred in 1830 by a war party of Sioux, Ho-Chunk, and Menominee.

This devastating event marked a turning point in Meskwaki history, and in Poweshiek's own life. It had happened during a journey, when virtually every significant Meskwaki leader of the time was traveling together to a peace council at Prairie du Chien where they had been invited, with reassurances, by federal Indian agent Joseph Street. On the way, as they stopped to prepare dinner, the Meskwaki leadership was attacked and massacred by a party of Sioux, Menominee, and Ho-Chunk. Historians of the incident detect complicity on the part of agent Street, who was working at that time to remove the Meskwaki from their lead mining operations near Dubuque, where Euro-Americans were contesting control of the mines. Meskwaki versions of the story say that one boy named Pe-to-wah survived but was too young to move into a leadership position. Absent a civil chief of the correct lineage, Poweshiek of the Brown Bear clan assumed leadership. It is not unlikely, then, that the skulls with bullet holes washing up on the banks of the Cedar were those of the Meskwaki chiefs massacred in 1830. Carried with Poweshiek's village, the remains would have been buried near the settlement on the Cedar only to be washed out by the river (Peterson, personal communication).

Encounters between Meskwaki and whites in Johnson County could also be extraordinarily violent. In the spring of 1838 , a trader on the Cedar River named Alexander Ross murdered a Meskwaki man at his trading post in Moscow. During the altercation Ross 
knocked down a man (reportedly Poweshiek's brother) with a rail, and then drove the rail "endwise into his skull, thus mashing his brains out." As was usual in affrays of any sort between white men and Indians, Ross was not punished; it was said that he ran away (Anonymous 726). Punishment eventually followed-but it would be according to Native practice rather than white law. Six months later the body of a white man named Oliver Atwood was discovered in a slough on the border between Johnson and Cedar Counties. The white settlers claimed Atwood was murdered by the Meskwaki in revenge for the brutal slaying of Poweshiek's brother by Ross: "the Indians were deeply aggrieved at the wrong," settlers recalled, "often alluding to it when intoxicated" (quoted in Peterson 85).

Atwood was an "exhorter," or Methodist preacher, who needed money. He had been working as a day laborer to help build a new trading post for the Meskwaki near Marengo. The Meskwaki were planning their next forced migration beyond the western boundary of the Second Black Hawk Purchase, and Wheaton Chase would be moving with them as their AFC trader. Chase had hired Atwood to help raise the new post. But, traveling home from work to Cedar County, Atwood never arrived. Five days later his body was discovered in the soggy slough eighty yards from the trail. It was not scalped, the county historian notes, but the legs were cut off, "with other marks of revengeful mutilation" that, according to the white settlers, gave evidence of Meskwaki agency. (Anonymous 586; 726).

Deaths and burials fill the archives of the Iowa River watershed during the 1830s. But what also emerges are episodes of intimate social experience, lived close to the mud, plants, animals, strangers, and kin on the river system that brought them together. Caroline Phelps's diary is a vivid memorial of a watershed environment that was at once commercial and communal, embodied and exploitative, entrepreneurial and everyday. In the summer of 1838 , for example, a large, energetic white man wandered into Phelps's trading post looking for an Indian tribe to join. Mrs. Phelps describes him as "a great big red headed fellow" who had shaved his beard to resemble Native warriors, claiming he wanted to join a Sauk and Meskwaki war party because he knew he could distinguish himself, if he could go to war with them. He wore "yellow jeans clothes," carried a sword at his side, and had black river mud smeared all over his head to keep the mosquitoes from biting him. But when he finally 
encountered some Sauk men at the trading post, they decided to have some fun with the aspiring warrior. Taking down Mrs. Phelps's clothesline, the men threatened to tie him up and said they were going to "strip him and paint him" across the river in the Sauk village. With that, the would-be white Indian broke away, begging for help, and ran off through the cornfields, with the Sauk or Meskwaki chasing after him, shooting, hollering, and screaming. They did not try hard to catch him, Mrs. Phelps notes, and "they were laughing heartily when they came back" (Phelps 239).

\section{GREEN YANKEES}

A wide variety of white immigrants, neither farmers nor townbuilders, wandered up along the Des Moines River Valley to the Phelpses' Iowaville trading post that winter. One was a prophet named Matthew from New York, an "old grey-headed, long bearded man, with a three cornered cap and a shotgun with a flag on the end, and a little white apron on." According to Mrs. Phelps, the prophet arrived at the trading post by walking across the frozen river ice, announcing that he was Christ and had come to see his "lambs," meaning the Indians. But when the old man went out to the Indians' camp, "the Sauk made signs to him not to come any nearer or they would shave him and paint him" (Phelps 238-9). Retreating to the trading post, he stayed two more days, in order to mend his clothes, and then went on his way.

In Mrs. Phelps's stories, the river plays a crucial supporting role, not only as a commercial route, but as a symbolic system and crosscultural interface: Matthew walks on the water, the red-headed warrior smears his face and neck with mud to ward off summer's mosquitoes, and the Sauk villagers keep the river between themselves and the AFC post. Such stories reveal that the multi-ethnic trading post was radically different from the towns and farms that followed, and that contact itself assumed diverse forms. Visitors and new settlers were greeted variously — with laughter, fear, curiosity, aggression, or sheer annoyance.

In spring of 1838 , for example, a group of Sauk and Meskwaki came down to the Phelpses' trading post from their maple sugar camp to complain that "white folks from the settlements" were bothering them. The Indians asked the Phelpses to go up to the sugar camp and "stay with them until they made sugar and keep the white folks 
from disturbing them." New to the Des Moines River, these white settlers "had the greens," as Mrs. Phelps explained, meaning they were extremely curious about seeing "Indians." While these "green Yankees," as she called them, had become seriously annoying to the Indians at the sugar camp, they were also bothering the Phelpses at their trading post, where they "came often to ask questions about Indians, and said they would like to see the Indians (just for greens)" (Phelps 237).

So William Phelps and his men decided to teach the Yankees a lesson. Phelps agreed to take the settlers to see Indians at the sugar camp, a quarter of a mile upriver, and set off with them one evening "along the path up the river bank." But all along the path, he had hidden his men with pistols and guns. As he approached the sugar camp with the Yankees in tow, he called a halt, saying that the Indians "maybe were drinking," and they should "stop close by and listen." Just then, one of his men fired a gun, and Phelps fell down "holler[ing] murder, murder." Terrified, the Yankees took off down the path back to the trading post, with Phelps's men firing their guns behind them "every rod almost on the way." When they reached the post, three of them rushed in to the central cabin, barring the doors and windows behind them. Phelps followed and, creeping up beneath a window, fired his pistol. The desperate Yankees tried to scramble under the beds, and one of them, the littlest fellow, hit his head and stood up, declaring, "O, I swow, what a damned time this is" (Phelps 237-8).

Mrs. Phelps and others at the post could hardly keep from laughing out loud, but, she writes, "we all acted our part." One of the Frenchmen living at the post had his wife there; he "besmeared himself with red paint" and collapsed on the floor pretending to die, while his wife pretended to cry over him. Hearing the noise and gunfire, the Sauk arrived from the sugar camp. They were told (by Phelps, perhaps, or by the post's interpreter) to sing their war song, which they did, and then "it really was quite a scene," concludes Mrs. Phelps, as those "fellows rushed out midst of fifty Indians,... jumping fences and woodpiles," with one even "roost[ing] in the top of a tree that night" (Phelps 238).

Like the Meskwaki in Johnson County, the Sauk had arrived after the cession of Keokuk's Reserve. Both Keokuk and the old warrior Black Hawk were living near the Phelpses' trading post during that 
maple sugar season of 1838. Perhaps the Yankees had the greens to see the famous "chief" Black Hawk, who had become a national celebrity when he was taken as a prisoner to tour the cities of the Northeast after the massacre at Bad Ax. Black Hawk's post-war tour was supposed to reveal the power of the United States to the stubborn Sauk, but Black Hawk himself quickly became the object on display, receiving newspaper coverage and huge audiences of Yankees eager to see "real Indians" in Boston, New York, and Philadelphia.

No doubt the Yankees at Phelps's post also had preconceptions about drunken binges at Indian camps, or murders and fights fueled by the whiskey sold at the trading posts throughout lower Wisconsin (soon-to-be Iowa) Territory. Trader Phelps seemed to play on such fantasies (and fact) when he whispered to the settlers to stop because the Indians "maybe were drinking." Ultimately, though, no matter what the voyeuristic Yankees imagined they would see at the sugar camp, they were mocked and tricked by Phelps because they were new, as well as green, in a fast-changing environment they did not fully understand.

Crucially, this environment was at once economic, ecological, and cultural. The socio-economic processes of fur trading, land speculation, and town building were concurrent and interconnected rather than sequential along the rivers of southeast Iowa. For instance, when Gilbert died at the Napoleon town site in 1839, he owned seventy acres of land in Muscatine County, twenty of them at Moscow, the area formerly served by Ross's trading post. Gilbert also owned thirty acres of timberland in Cedar County surrounded by 130 acres of prairie, "mostly wet." As State Archaeologist Cindy Peterson points out, this site, with its small timbered tributary, would have been an optimal location for a Meskwaki maple sugar camp (87). Gilbert possessed another 160 acres of prairie in Cedar County and some eighty acres in Johnson County, while competitor Wheaton Chase owned several hundred acres of land in Johnson County, much of which he sold in 1840 for $\$ 700$.

Neither geomorphology nor aesthetics alone can explain Iowa City's location on the Iowa River between Snyder Creek and Ralston and Rapid Creeks. In the spring of 1839, John Ralston and Chauncey Swann were commissioned by Governor Lucas to determine the site of the new capital city. On May Day the two men planted a stake on the bluffs above the river near Napoleon, where 
the land, they explained, "was shaped like an amphitheater." But their choice does not, finally, explain very much. The bluffs, rolling prairie, and curve of the river that made the site desirable could have been found at many other locations, on any number of Iowa rivers. The emergence of Iowa City on the Iowa River, sixty miles west of Saukenuk/Rock Island, only makes sense when it is viewed in the context of the Sauk and Meskwaki land cessions of the 1830 . Why did the town emerge there, and then? The answer lies with the Meskwaki villagers and American Fur Company traders who migrated up the Iowa River watershed, and whose economic interests and social intimacies preceded the farms and towns, schools and factories that followed.

\section{Bibliographic Note}

This essay could not have been written without the scholarship and assistance of historian Mary Bennett of the Iowa State Historical Society and archaeologist Cindy Peterson at the State Archaeologist's Office in Iowa City. Much of what I know of Meskwaki history I have learned through personal communication with Mary Bennett and Johnathan Lanz Buffalo, and from the website and CD produced by Mary Bennett, Johnathan Lanz Buffalo, and Dawn Suzanne Wanatee, Meskwaki History (State Historical Society of Iowa, Department of Cultural Affairs, 2004) which contains, among other things, the fullest bibliography available on Meskwaki language, culture, and history. Cynthia L. Peterson's 1997 Sand Road Heritage Corridor, Johnson County, Iowa: Archaeology and History of Indian and Pioneer Settlement (Office of the State Archaeologist Report \#492) was generously provided by osA archivist Julie Hoyer. Cindy Peterson's astoundingly rich report details everything known to date about John Gilbert, his trading post, and his contact with Meskwaki villages and immigrant settlers in Johnson County between 1835 and 1839. John F. Doershuk's and Cynthia L. Peterson's 2005 Phase I Intensive Archaeological Survey of a Proposed Wetland Impoundment Project, Hawkeye Wildlife Management Area, T81N-R8W, Johnson County, Iowa (Office of the State Archeologist Report \#1342) offers a fascinating account of the only excavated location of one of Powesheik's villages near the 1839-1849 "paper town" of Monroe above the Coralville Reservoir. An overview of the archaeology of 
seasonal migrations and food production practices among Native peoples on the Iowa River can be found in James Collins, The Iowa River Greenbelt: An Archaeological Landscape (Iowa City: The University of Iowa, 1991), while the definitive survey of trading post, fort, and village sites in the 1830 is Kathryn E. Gourley, Locations of Sac, Mesquakie, and Associated Euro-American Sites 1832-1845: An Ethnohistoric Approach (unpublished master's thesis, Department of Anthropology, Iowa State University, Ames, 1990). Other sources for early Johnson County history include Anonymous, History of Johnson County, Iowa, Containing a History of the County, and its Townships, Cities, and Villages from 1836 to 1882 (Iowa City: no publisher listed, 1883); Charles R. Aurner, Leading Events in Johnson County, Iowa, History (Western Historical, Cedar Rapids, Iowa, 1912), and M. Etta Cartwright Coxe, n.d., "Poweshiek's Oration and Reminiscences" (typescript, Manuscripts Division, State Historical Society of Iowa, Iowa City). Caroline Phelps's Des Moines River diary is published in the Journal of the Illinois State Historical Society 23: 209-239; details of Poweshiek's feathered cape can be found in Duane C. Anderson, "Mesquakie Chief Poweshiek's Feathered Cape," Plains Anthropologist 30 (1985): 161-164. For an introduction to the history of the American Fur Company, see John Denis Haeger, John Jacob Astor, Business and Finance in the Early Republic (Wayne State University Press, 1991), and David Lavender, The Fist in the Wilderness (New York: Doubleday and Company, 1964). The best analysis of the significance of Black Hawk's War in the history of U.S. national expansion is Kerry A. Trask, Black Hawk: The Battle for the Heart of America (New York: Henry Holt and Company, 2007). Michael D. Green helps to explain the relationship of alliance and separation between Sauk and Meskwaki in the early nineteenth century in "We Dance in Opposite Directions': Mesquakie (Fox) Separatism from the Sac and Fox Tribe," Ethnohistory 30(3): 129-140. 